17 McDermot AG, Marble AE, Yabsley RH, Phillips MB. Monitoring dynamic anterior compartment pressures during exercise:a new technique using the STIC catheter. $\mathrm{Am}$ I Sports Med 1982;10:83-9.

18 Styf J, Korner L, Suurkula M. Intramuscular pressure and . muscle blood flow during exercise in chronic compartmen
19 Logan JG, Rorabeck CE, Castle GSP. The measurement of dynamic compartment pressure during exercise. $\mathrm{Am} \mathcal{f}$ Sports Med 1983;4:220-3.

20 Rorabeck CH, Bourne RB, Fowler PJ, Finlay JB, Nott L. The role of tissue pressure measurement in diagnosing chronic anterior compartment syndrome. Am $₹$ Sports Med chronic anterior

\title{
Late deterioration after decompression illness affecting the spinal cord
}

\author{
J Dyer, P Millac
}

\begin{abstract}
A former amateur diver presented with a progressive paraparesis. Thirteen years previously he had developed acute spinal cord dysfunction immediately after dry hyperbaric exposure. He had completely recovered motor function in the intervening period. No alternative reason for the later decline emerged from detailed investigation.

(Br F Sports Med 1996;30:362-363)
\end{abstract}

Key terms: decompression illness; late paraparesis

Dysbarism (decompression illness) is one of the most common identifiable causes of nontraumatic ischaemic myelopathy. ${ }^{1}$ Histological examination of the spinal cord of divers who have suffered dysbarism can reveal widespread damage, with hyalinised blood vessels and demyelination, even in those who have subsequently recovered. There may also be degeneration of nerve fibres in the dorsal and lateral spinal columns, with gliosis and white matter atrophy. ${ }^{2-6}$

\section{Case report}

A 37 year old Caucasian man presented with weakness and spasticity of his legs, worsening since the onset six months earlier.

Thirteen years previously he had suffered a spinal cord decompression illness. At no other time had he had any significant disease or diving accident. The decompression illness was experienced following a closely monitored hyperbaric exposure to a maximum of 6.5 atmospheres. He shared the compression chamber with four other divers, none of whom was adversely affected. The chamber pressure was controlled from outside following the standard national guidelines then available (1978).

Thirty minutes after recompression he experienced paraesthesia in his right buttock. After one hour he had developed weakness of both legs (MRC grade 3/5). He managed to return to the chamber for therapeutic recompression within $2 \frac{1}{2}$ hours, which was at 6 atmospheres for $5 \frac{1}{2}$ hours. During this period his decompression illness deteriorated, most notably in that he developed urinary retention, which required catheterisation. He also had reduced pin prick, light touch, and temperature sensation below his umbilicus, with pain around his lumber spine. Vibration and proprioception sense were unaffected; his legs remained as weak though he now showed hyperreflexia. After transportation to a Royal Navy base he had further recompression. The following day he had a third recompression but on this occasion breathing oxygen enriched air. Over these two days there was a steady recovery to normality, with the exception of a slight deficit in light touch and proprioception below his umbilicus and a bandlike sensation around his waist. Negative investigation in the weeks following this were: CSF and urine microscopy, blood urea and electrolytes, glucose, full blood count, VDRL, chest $x$ ray, electromyelography, visual evoked responses, and whole spine myelography.

Without further dives he presented 13 years later with spastic paraparesis developing over six months. His minor sensory impairment was unchanged. Bladder, bowel, and sexual function are unaffected. He has never taken regular medication, drank alcohol moderately, has no relevant family history, but had recently become so incapacitated that he was unable to continue as a building contractor. All leg muscles have MRC grade 4/5 power with increased tone, global hyperreflexia, and extensor planter reflexes. The previous investigations remained normal, as did his HTLV 1, CSF electrophoresis for IgG, and magnetic resonance imaging (MRI; T2 weighted spin echo) of his brain.

MRI of his cervical and thoracic spine (T1 weighted spin echo), scanned in sagittal and axial section, showed focal narrowing of the cord between $\mathrm{T} 2$ and $\mathrm{T} 7$, with expansion at either end to normal calibre. In the narrow section there is increased epidural fat, indicating that this is a long standing lesion (figure).

Over the four years following this latter deterioration, his neurological condition worsened only subjectively. Presently he requires walking sticks but otherwise reports no new changes. 


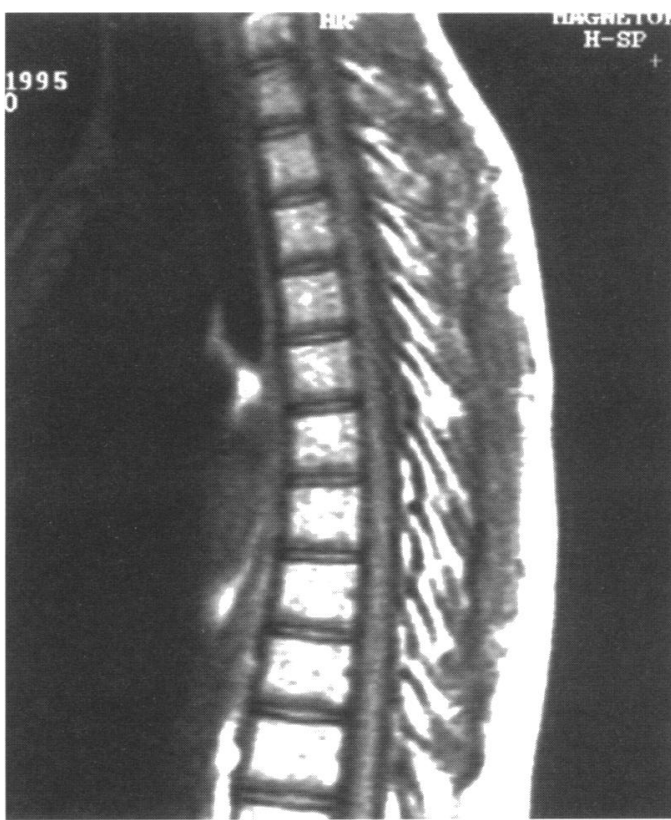

Magnetic resonance imaging (MRI; T1 weighted spin echo sequence) of the thoracic spine, in the mid-sagittal plane. This example of a normal spine has been acquired on a $1^{\frac{1}{2}}$ Tesla scanner and shows the cord as a pale (high signal), relatively uniform structure, surrounded by a thin layer of CSF (low signal). The cord lies posterior to the vertebral bodies (seen as pale structures due to the contained marrow fat).

\section{Discussion}

A very similar case has been described ${ }^{3}$ in which decompression illness manifested as pain and tightness in a girdle distribution, with left leg weakness and right leg anaesthesia. Four years later, although asymptomatic, the patient had brisk snout and leg reflexes with positive palmo-mental reflexes. Soon after the latter examination this diver was killed in a road accident. Necropsy showed the typical histological changes in the spinal cord of decompression illness outlined in the introduction.
During the building of the Budapest Metro, 10 divers complained of the symptoms of spinal cord decompression illness. Subsequently their progress was monitored at outpatient clinic; although seven continued to show abnormal reflexes, only four reported any neurological impairment. ${ }^{7-8}$

The slight or absent functional deficit, despite severe and widespread structural damage following decompression illness, has been termed the "iceberg phenomenon". ${ }^{8}$ However, our search of published reports revealed surprisingly that this case is unprecedented. Nevertheless, we believe that any other cause of myelopathy other than late degeneration secondary to decompression illness is implausible with this clinical history, with the MRI changes, and with the present relative stability following the deterioration.

The mechanism for this further degeneration may be the inability of the spinal cord to compensate for aging or vascular change, or alternatively an increased vulnerability to exogenous agents.

1 Kim SW, Kim RC, Choi BH, Gordon SK. Non-traumatic ischaemic myelopathy. Paraplegia 1988;26:262-72.

2 Aita JA. Neurologic manifestations of dysbarism. In: Vinken PJ, Bruyn GW, eds. Vascular diseases of the nervous system. Handbook of clinical neurology, vol 12. Amsterdam: North Holland Publishing Co, 1972:665-76.

3 Palmer AC, Calder IM, McCallum RI, Mastaglia FL. Spinal cord degeneration in a case of "recovered" spinal decompression sickness. BMF 1981;283:888

4 Mastaglia FL, McCallum RI, Walder DN. Myelopathy associated with decompression sickness. Clin Exp Neurol 1983; 19:54-9.

5 Palmer AC, Calder IM, Hughes JT. Spinal cord degeneration in divers. Lancet 1987; ii: $1365-6$.

6 Strauss RH, Prockop LD Decompress sickness among scuba divers. $\mathfrak{F} A M A$ 1973;223:637-40.

7 Rozsahegyi I. Late consequences of the neurological forms of decompression sickness. Br f Indust Med 1959;16:311-7. of decompression sickness. Br f Indust Med 1959;16:31 1-7.
Rozsahegyi I, Soos I. Caissonkrankheit und ZentralnervensysRozsahegyi I, Soos I. Caissonkrankheit und Zentralnervens

9 Calder I. Does diving damage your brain? Occup Med 1992; 42:213-4. 